Article

\title{
Spatial Effects of Domestic Tourism on Urban-Rural Income Inequality
}

\author{
Zhixin Zeng ${ }^{1, *(\mathbb{D})}$ and Xiaojun Wang ${ }^{1,2}$ \\ 1 Center for Economics, Finance and Management Studies (CEFMS), Hunan University, Shijiachong Road, \\ Yuelu District, Changsha 410006, China; xiaojun@hawaii.edu \\ 2 Department of Economics, University of Hawaii, Honolulu, HI 96822, USA \\ * Correspondence: zhixinzeng@hnu.edu.cn; Tel.: +86-19229880704
}

\section{check for}

updates

Citation: Zeng, Z.; Wang, X. Spatial Effects of Domestic Tourism on Urban-Rural Income Inequality. Sustainability 2021, 13, 9394. https://doi.org/10.3390/su13169394

Academic Editor: Gema Cárdenas

Received: 30 June 2021

Accepted: 19 August 2021

Published: 21 August 2021

Publisher's Note: MDPI stays neutral with regard to jurisdictional claims in published maps and institutional affiliations.

Copyright: (C) 2021 by the authors. Licensee MDPI, Basel, Switzerland. This article is an open access article distributed under the terms and conditions of the Creative Commons Attribution (CC BY) license (https:// creativecommons.org/licenses/by/ $4.0 /)$.

\begin{abstract}
Although much of the recent research has explored the relationship between domestic tourism and income inequality among regions, provinces, and cities, few studies have examined the impact of domestic tourism on income inequality between urban and rural areas within a region. This paper uses a panel dataset covering China's 31 provinces for 21 years to investigate the spatial spillover effect of domestic tourism on urban-rural income inequality. An increase in domestic tourism revenue in neighboring provinces leads to a reduction in the local province's urbanrural income inequality. Innovatively, we decompose domestic tourism revenue and consider the circumstances in different provinces. An increase in the number of neighboring provinces' domestic tourists' arrival decreases the local province's urban-rural income inequality in western provinces but increases the inequality in eastern provinces; the effect is insignificant in central provinces. In order to improve urban-rural income inequality by attracting domestic tourists, this study suggests a collaborative strategy for the western region, a low-priority strategy for the central region, and a mitigation strategy for the eastern region.
\end{abstract}

Keywords: domestic tourism; spatial spillovers; urban-rural income inequality

\section{Introduction}

Income inequality poses a significant threat to health equity, education justice, economic growth quality, social integration, and sustainable development [1]. According to the pro-poor growth theory and the trickle-down effect, domestic tourism can reduce income inequality [2-4]. Empirical studies have supported the role of domestic tourism on income inequality in Sapa, Vietnam [5], Brazil [6], and 60 countries [7]. However, existing research mainly focuses on domestic tourism's effect on income inequality among regions, provinces, and cities $[4,8,9]$, and studies concerning the impact of domestic tourism on urban-rural income inequality are rare.

Urban-rural income inequality herein means the income inequality between urban areas and rural areas. China's income inequality problem has been severe in recent years [10]. China's urban-rural income inequality attracts more attention because China has registered one of the highest urban-rural income ratios in the world [11]. From 1997 to 2019, the mean per capita disposable income of urban residents was three times higher than that of rural residents [12]. According to Chang [13], urban-rural income inequality is "the most critical factor" of China's income inequality. Therefore, it is important to understand this main driver of income inequality.

This article conducts an empirical evaluation of domestic tourism's spillover effects on income inequality between urban areas and rural areas within provinces based on a sample of 31 provinces in China from 1998 to 2018. First, this study examines the spillover effects by using weight matrices based on geographical location, geographical distance, and the shortest railway time. Second, this study decomposes domestic tourism revenue and considers circumstances in different provinces. 
This study supplements the existing literature on domestic tourism's impact on income inequality by focusing on urban-rural income inequality with spatial spillover effects. Our results could help the government design policies that reinforce the pro-poor impact of domestic tourism. We expect the study to provide provinces in different regions with concrete strategies to achieve domestic tourism's positive role in improving urban-rural income equality effectively.

\section{Literature Review}

The literature regarding the effect of tourism on income inequality has three different concerns. The first concern is income inequality, such as geographic scope and population scope. The second indicates that domestic tourism may be mixed with international tourism as tourism. The third studies the spatial effects of income inequality and tourism.

\subsection{Income Inequality}

There already exists a huge amount of literature focusing on the impacts of tourism on income across countries, provinces, or regions. Williams and Shaw [14] suggest that tourism extends development from developed centers to less developed areas. For instance, Li et al. [4] suggest that domestic tourism could narrow economic inequality among Chinese provinces. Theoretically, tourism can affect income inequality by three channels: changes in prices, earnings of households, and government revenues [15].

The literature on tourism's impact on the poor or rural residents substantially outnumbers the studies on domestic tourism's impact on both rural and urban residents. Mitchell and Ashley [16] point out pro-poor assessment of tourism. Ample empirical evidence supports the view that tourism development influences the poor, such as in Sapa, a popular tourist destination in Vietnam [5], in American rural areas [17], in tourism-intensive economies [2], and in developing economies [7,18,19]. Mahadevan and Suardi [2] recommend using relative poverty or the poverty gap as a measure to assess tourism's impact on income distribution.

Due to a series of urban-biased policies during the central planning era, urban-rural income inequality in China is one of the highest in the world [11] and is the main reason for the great nationwide disparity in China [13]. Liu et al. [20] consider it one of the main bottlenecks straining sustainable development. Research examining the effects of tourism on the income inequality between urban and rural residents within areas is more limited and, hence, is more critically needed.

\subsection{Tourism}

The literature regarding the impact of tourism on urban-rural income inequality in China usually considers domestic and international inbound tourism as a whole. For instance, using the data from 30 provinces from 1999 to 2008, Zhao [21] finds that tourism significantly increases the rural per capita real income but has no impact on urban per capita real income.

A notable exception is the research of Shi et al. [22], who investigate the effect of inbound tourism on urban-rural income inequality. They report that local and neighboring inbound international tourism in western China significantly improve local urban-rural income equality. In addition, they indicate that neighboring inbound tourism significantly increases local urban-rural income inequality in the eastern region.

Domestic tourism represents a large share of the total tourism volume in China. However, no prior study has addressed domestic tourism's role in reducing urban-rural income inequality.

\subsection{Spatial Effects}

Prior research has shown the spatial effects of income inequality. Sampson [23] highlights a theory of neighborhood effects of income inequality among American cities. Reardon and Bischoff [24] suggest that income inequality influences the large-scale spatial 
segregation of affluence, and then affects income segregation. In China, the distribution of the rural poor exhibits an obvious spatial agglomeration feature [25]. In central and western China, poverty appears to be concentrated in remote deep mountainous areas, minority areas, and border areas among the provinces; poverty also gathers in southwestern China.

A series of studies have indicated spatial spillover effects of domestic tourism development in many countries, such as Italy [26], Spain [27], and Korea [28]. In China, Yang and Fik [29] recognize the positive spatial spillover effects in domestic tourism's growth rate. Moreover, Ma et al. [8] find that domestic tourism has a significant positive spillover effect on China's urban economic growth, although the direct effect on local economies is negligible.

Therefore, it is necessary to capture this spatial spillover effect by specifying a spatial dependence term in the empirical model, which assumes that income inequality of a particular province is influenced by income inequality of its neighboring provinces [30]. Similarly, we should consider that the effect of domestic tourism in a particular province might affect domestic tourism of its neighboring provinces. Controlling for the spatial spillover effects in the models can alleviate the bias in estimates of the province-level effects.

This study fills the literature gap by analyzing domestic tourism's influence on urbanrural income inequality and using a spatial analysis method to investigate domestic tourism's impacts in local and neighboring regions simultaneously. In line with the existing literature on urban-rural income inequality, this paper uses the ratio of urban disposable income per capita to rural disposable income per capita in a province to measure the ratio of urban-rural income inequality in that province.

Based on the literature, we propose two hypotheses to precisely address whether and to what extent domestic tourism influences urban-rural income inequality.

Hypothesis 1 (H1). Domestic tourism development in the local province negatively affects the ratio of urban-rural income inequality in that province.

Hypothesis 2 (H2). Domestic tourism development in neighboring provinces negatively affects the ratio of urban-rural income inequality in the local province.

\section{Empirical Model and Data}

3.1. Regression Model

Based on the panel spatial Durbin model (hereafter referred to as SDM) [30], the estimation function is formulated as follows:

$$
Y_{i, t}=\rho \sum_{j=1}^{n} w_{i j} Y_{j, t}+\alpha X_{i, t}+\beta \sum_{j=1}^{n} w_{i j} X_{j, t}+\mu_{i}+\varepsilon_{i, t}
$$

where $i$ and $\mathrm{j}$ represent the local and neighboring provinces, respectively; $\mu_{\mathrm{i}}$ is the individual effect; and $\varepsilon$ is the error term. In the panel model, $u$ stands for the fixed effect if we apply a fixed effect SDM (FE-SDM), or the random effect if we apply a random effect SDM (RE-SDM). The spatial autoregressive coefficient is $\rho$, and $\alpha$ and $\beta$ are the coefficients to be estimated. In the framework of the SDM, these coefficients do not reflect the sign and magnitude of the impact of a change in a given independent variable on the dependent variable [30].

In our analysis, the dependent variable $Y$ refers to $\ln (\mathrm{URII})$, the logarithmic value of the ratio of urban disposable income per capita to rural disposable income per capita. The vector $\mathrm{X}$ comprises a set of explanatory variables. The core explanatory variable of interest is $\ln (\mathrm{DOM})$, the logarithmic value of domestic tourism revenue (in 100 million renminbi (RMB) Yuan, 2010 prices) in a province. In the baseline model, the variable $\ln (\mathrm{DOM})$ proxies the domestic tourism development level. The alternative measure of domestic tourism development level is $\ln (\mathrm{DOM}$-Tourist), which is equal to the logarithmic value of the number of domestic tourist arrivals (10,000 person-times) and will be used for a robustness check. 
In addition, we also consider three important control variables:

1. $\ln (\mathrm{GDP})$ is the logarithmic value of the gross domestic product (GDP) in a province. This variable measures the overall degree of economic development.

2. Tertiary is the GDP share of the tertiary industries. The variable is included to control for the possible effect for localization economies [29].

3. Urbanization is measured by the population density (in person $/ \mathrm{km}^{2}$ ). This variable intends to capture the role of urbanization in urban-rural income inequality [29].

$\mathrm{w}_{\mathrm{ij}}$ represents a spatial weight matrix. We use a queen contiguity weighting matrix, $w^{\text {neighbor }}$, in our baseline model. The diagonal element $w_{i j}^{\text {neighbor }}(i=j)$ is zero. The offdiagonal element $w_{i j}^{\text {neighbor }}(i \neq j)$ is set equal to one if the provinces $i$ and $j$ are neighbors (sharing a common border or vertex) and zero otherwise [31]. Hainan province, an isolated island province without land borders, was a part of Guangdong province until 1988 and is treated as the neighbor of Guangdong province [32]. Alternative spatial weight matrices based on the geographic distance between provincial capitals and railway travel time are also used for a robustness check.

\subsection{Data}

This paper uses a balanced panel dataset of 31 Chinese provinces (excluding Taiwan, Hong Kong, and Macao), annually from 1998 to 2018, which yields 651 total observations. Table 1 reports the variable definitions and Table 2 provides summary statistics. We construct the spatial weight matrices regarding the geographic locations or distance based on the longitude and latitude data from the National Geomatics Center of China. To build the spatial weight matrices based on railway travel time, we utilize data from the National Railway Passenger Timetable (1995-1996) [33].

Table 1. Variable definition.

\begin{tabular}{|c|c|}
\hline Variables & Definition \\
\hline $\ln (\mathrm{URII})$ & $\begin{array}{c}\text { The logarithmic value of the ratio of urban disposable income per capita to rural disposable income } \\
\text { per capita. }\end{array}$ \\
\hline $\ln (\mathrm{DOM})$ & $\begin{array}{c}\text { The logarithmic value of domestic tourism receipts (in } 100 \text { million RMB Yuan, } 2010 \text { prices) in a } \\
\text { province during one year. }\end{array}$ \\
\hline $\ln (\mathrm{DOM}$ _Tourist $)$ & The logarithmic value of the number of domestic tourist arrivals (10,000 person-times). \\
\hline $\ln (\mathrm{DOM}$ _Expenditure) & The logarithmic value of domestic tourists' average expenditure (yuan, at 2010 prices). \\
\hline $\ln (\mathrm{GDP})$ & The logarithmic value of the gross domestic product (GDP) in a province during one year. \\
\hline Tertiary $(\%)$ & The percentage of GDP from tertiary industries relative to the overall GDP. \\
\hline Urbanization & The population density (in person $/ \mathrm{km}^{2}$ ). \\
\hline
\end{tabular}

Note: The Statistical Yearbook of China at provincial levels, 1999-2019.

Table 2. Summary statistics.

\begin{tabular}{ccccc}
\hline Variables & Mean & Std. Dev & Minimum & Maximum \\
\hline $\ln ($ URII) & 1.023 & 0.208 & 0.484 & 1.652 \\
$\ln ($ DOM $)$ & 15.552 & 1.797 & 9.104 & 18.866 \\
$\ln ($ DOM_Tourist) & 8.95 & 1.416 & 3.368 & 11.479 \\
$\ln ($ DOM_Expenditure) & 6.679 & 0.404 & 5.351 & 7.83 \\
$\ln ($ GDP) & 8.756 & 1.386 & 4.312 & 11.679 \\
Tertiary (\%) & 41.286 & 8.591 & 27.411 & 80.982 \\
Urbanization & 408.485 & 594.323 & 2.096 & 3826.197 \\
\hline
\end{tabular}

Note: 651 observations for each variable.

\section{Results}

\subsection{Statistical Tests of Spatial Autocorrelation}

Table 3 presents the estimated value of Moran's I and the associated z-score for $\ln (\mathrm{URII})$ and $\ln (\mathrm{DOM})$ in each sample year, as well as their average values during the sample years. 
Urban-rural income inequality and domestic tourism revenue both display a statistically significant spatial autocorrelation. Significant signs of a spatial autocorrelation mean that the distributions of urban-rural income inequality and domestic tourism development demonstrate substantial spatial agglomeration.

Table 3. Statistical tests of spatial autocorrelation by Moran's I.

\begin{tabular}{|c|c|c|c|c|}
\hline \multirow[t]{2}{*}{ Year } & \multirow{2}{*}{$\begin{array}{c}\ln \text { (URII) } \\
\text { Moran's I }\end{array}$} & \multicolumn{3}{|c|}{$\ln (\mathrm{DOM})$} \\
\hline & & z Score & Moran's I & z Score \\
\hline 1998 & $0.642 * * *$ & 5.770 & $0.398^{* * *}$ & 3.716 \\
\hline 1999 & $0.664^{* * *}$ & 5.931 & $0.390^{* * *}$ & 3.613 \\
\hline 2000 & $0.668^{* * *}$ & 5.940 & $0.378^{* * *}$ & 3.541 \\
\hline 2001 & $0.678^{* * *}$ & 6.021 & $0.379^{* * *}$ & 3.547 \\
\hline 2002 & $0.636^{* * *}$ & 5.687 & $0.383^{* * *}$ & 3.566 \\
\hline 2003 & $0.597^{* * *}$ & 5.352 & $0.379^{* * *}$ & 3.520 \\
\hline 2004 & $0.580 * * *$ & 5.197 & $0.364^{* * *}$ & 3.397 \\
\hline 2005 & $0.530 * * *$ & 4.810 & $0.363^{* * *}$ & 3.397 \\
\hline 2006 & $0.520 * * *$ & 4.737 & $0.355^{* * *}$ & 3.314 \\
\hline 2007 & $0.539 * * *$ & 4.878 & $0.340^{* * *}$ & 3.184 \\
\hline 2008 & $0.546^{* * *}$ & 4.904 & $0.345^{* * *}$ & 3.264 \\
\hline 2009 & $0.529 * * *$ & 4.774 & $0.360^{* * *}$ & 3.353 \\
\hline 2010 & $0.515^{* * *}$ & 4.644 & $0.347^{* * *}$ & 3.253 \\
\hline 2011 & $0.521^{* * *}$ & 4.654 & $0.330^{* * *}$ & 3.120 \\
\hline 2012 & $0.513^{* * *}$ & 4.607 & $0.319^{* * *}$ & 3.027 \\
\hline 2013 & $0.442^{* * *}$ & 4.043 & $0.303^{* * *}$ & 2.894 \\
\hline 2014 & $0.457^{* * *}$ & 4.138 & $0.300^{* * *}$ & 2.859 \\
\hline 2015 & $0.438^{* * *}$ & 3.980 & $0.269^{* * *}$ & 2.612 \\
\hline 2016 & $0.430 * * *$ & 3.909 & $0.248^{* *}$ & 2.436 \\
\hline 2017 & $0.417^{* * *}$ & 3.798 & $0.251^{* *}$ & 2.458 \\
\hline 2018 & $0.404^{* * *}$ & 3.693 & $0.235^{* *}$ & 2.331 \\
\hline Average & $0.592^{* * *}$ & 5.271 & $0.357^{* * *}$ & 3.357 \\
\hline
\end{tabular}

Note: The Moran's I index value was calculated by using the data of the logarithm of urban-rural income inequality, $\ln (\mathrm{URII})$, and the logarithm of domestic tourism revenue, $\ln (\mathrm{DOM})$, in 31 of China's provinces and regions for each year from 1998 to 2018, as well as the averaged values. The null hypothesis is no global spatial autocorrelation. Superscripts ${ }^{* * *}$ and ${ }^{* *}$ indicate statistical significance at the $1 \%$ and $5 \%$ levels, respectively.

Figure 1 shows the urban-rural income inequality, averaged across the entire sample period. The average values are always greater than one, suggesting that urban-rural income inequality prevailed in all 31 provinces. Moreover, neighboring provinces clearly demonstrate a similar degree of the income inequality, indicating a special agglomeration of the effects.

In a similar vein, Figure 2 presents the annual domestic tourism revenue, averaged across the entire sample period. The pattern is clear: domestic tourism revenue is the highest in the eastern region, followed by the central and the western regions.

There may be two limitations by using the provincial data instead of the geographic data from smaller units. First, the value of annual domestic tourism revenue for each province is the total value at the provincial level, instead of the average per unit area. This may lead to higher values in provinces with large geographic areas, which means that the values may be much higher in western China than in eastern China as a byproduct due to the fact that the units of analysis are much larger geographically in western China than in eastern China. However, the opposite is true. The values in eastern China are much higher than in western China in Figure 2. Second, the results are different for western and eastern China, which may make perfect sense given the population densities, income levels, and transportation infrastructure. However, even considering the different circumstances of the population and administrative area in each province, the condition that tourism development level is higher in eastern China than in western China still exists (See Figures A1 and A2). Hence, these two limitations do not seem to distort the level 
of tourism development. In order to obtain accurate estimation results, the population distribution, economic levels, and tertiary industry development should be considered in the empirical analysis.

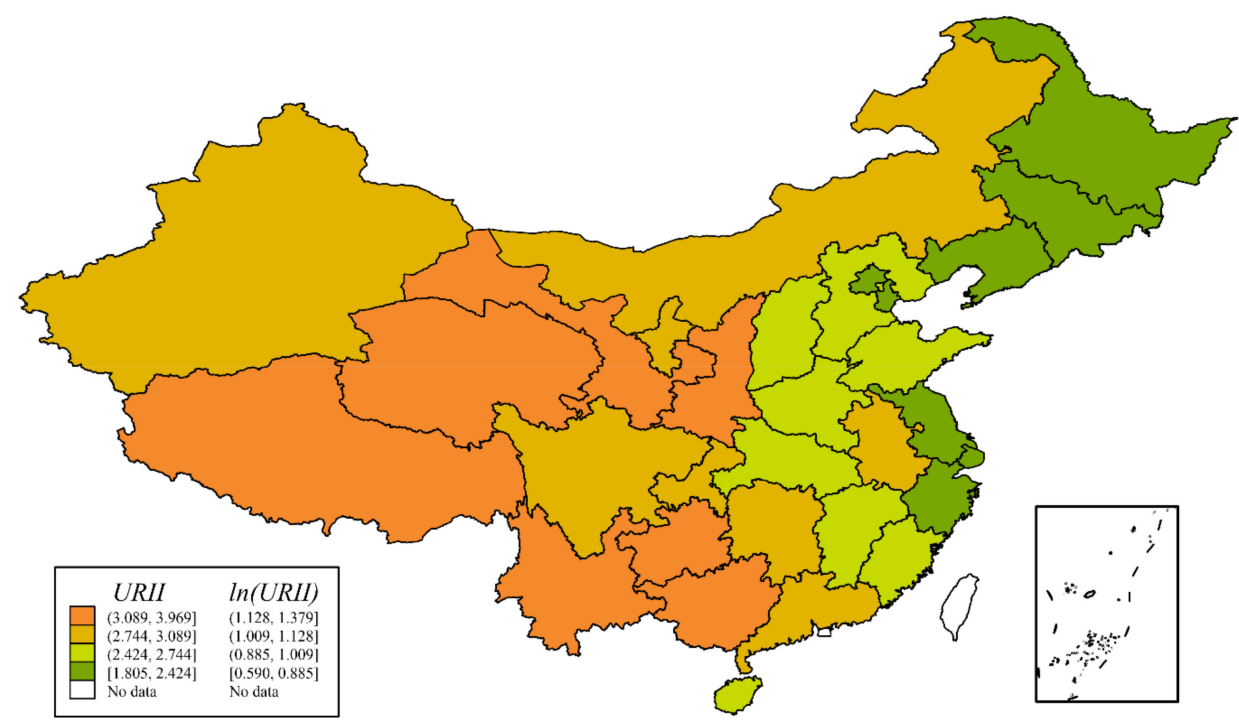

Figure 1. Spatial distribution of $\ln ($ URII) (average value from 1998 to 2018). $\ln$ (URII) is the logarithm of the ratio of urban disposable income per capita to rural disposable income per capita.

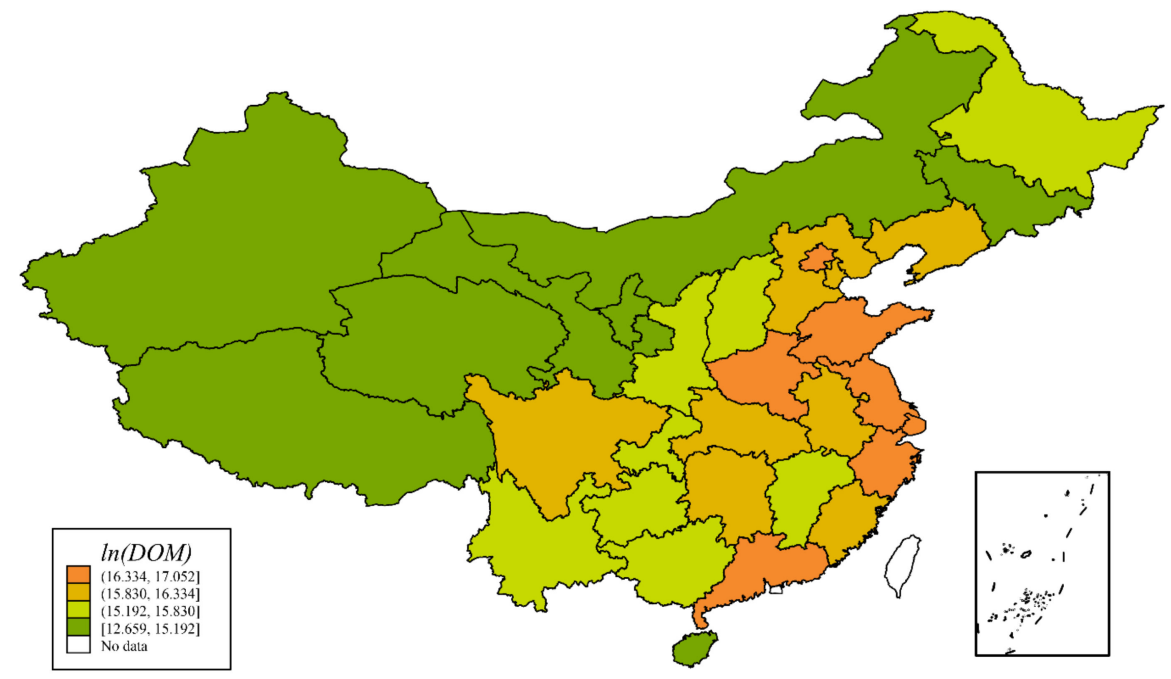

Figure 2. Spatial distribution of $\ln (\mathrm{DOM})$ (average value from 1998 to 2018). $\ln (\mathrm{DOM})$ is the logarithm of the total real revenue of domestic tourism (100 million RMB Yuan, at 2010 prices).

The above preliminary evidences firmly support that the distributions of domestic tourism revenue and urban-rural income inequality are geographically regular and have demonstrated substantial spatial agglomeration. Ignoring the spatial spillover effects may yield biased estimates. Hence, this research adopts spatial econometric models and incorporates the spatial spillover effects among the dependent and independent variables. Furthermore, these results imply that it is necessary to check whether the spillover effects are homogeneous over western, central, and eastern China.

\subsection{Main Estimation Results}

This section reports the main estimation results based on the baseline model. Before estimating the SDM, we first utilize the Hausman test to determine whether we should 
apply an FE model or an RE model. The Hausman test $(49.27, p=0.00)$ indicates that the FE-SDM is preferred. Within a framework of the SDM, the independent variables' coefficient does not correctly reflect the sign and magnitude of the impacts of a change in a given independent variable on the dependent variable [30]. This is because, with spatial lags of the independent and dependent variables in the model, these coefficients may include the feedback effects through spatial spillovers effects.

To overcome this problem, column (1) of Table 4 provides the estimated direct, indirect, and total effects of $\ln (\mathrm{DOM})$ on $\ln (\mathrm{URII})$. The direct effect was -0.044 with a statistical significance at the $1 \%$ level, indicating that a $1 \%$ increase of domestic tourism revenue leads to a decline of $0.044 \%$ in the urban-rural income inequality ratio. In our sample, across all provinces, the mean value of domestic tourism revenue increased by $22 \%$ annually during 1998-2018, and the average urban-rural income inequality ratio in 1998 was 2.51 . Thus, from 1998 to 2018, the increase in domestic tourism revenue corresponds to a reduction of 0.44 in the urban-rural income inequality ratio, i.e., from 2.51 to 2.05 , a considerable improvement. The indirect effect is -0.124 and is statistically significant at the $5 \%$ level, indicating that the local urban-rural income inequality would decrease by $0.124 \%$ if domestic tourism revenue in all neighboring provinces simultaneously increased by $1 \%$. The indirect effect is substantial, equivalent to three times that of the direct effect. The total effect is -0.168 , which implies that a simultaneous increase in domestic tourism in local and neighboring provinces decreases the local province's urban-rural income inequality. This phenomenon can be explained by the pro-poor effect of tourism (i.e., tourism delivers more net benefits to the poor) [20].

Table 4. Estimated direct, indirect, and total effects (baseline model and robustness check).

\begin{tabular}{|c|c|c|c|c|c|}
\hline & \multirow{3}{*}{$\begin{array}{c}\text { Baseline } \\
\text { FE Model }\end{array}$} & \multicolumn{4}{|c|}{ Robustness Check } \\
\hline & & \multicolumn{3}{|c|}{ With Alternative Spatial Weight Matrix } & \multirow{2}{*}{$\begin{array}{r}\text { Alternative Index o } \\
\text { Domestic Tourism }\end{array}$} \\
\hline & & $w^{3-n e a r e s t}$ & $w^{15-h}$ & $\mathbf{w}^{\text {inverse-time-squared }}$ & \\
\hline & (1) & (2) & (3) & (4) & (5) \\
\hline $\begin{array}{l}\text { Direct effect } \\
\ln (\mathrm{DOM})\end{array}$ & $\begin{array}{c}-0.044^{* * *} \\
(-4.40)\end{array}$ & $\begin{array}{c}-0.056^{* * *} \\
(-5.37)\end{array}$ & $\begin{array}{c}-0.084 * * * \\
(-7.11)\end{array}$ & $\begin{array}{c}-0.056^{* * *} \\
(-5.30)\end{array}$ & \\
\hline $\ln \left(\mathrm{DOM} \_\right.$Tourist $)$ & & & & & $\begin{array}{c}-0.096^{* * *} \\
(-8.40)\end{array}$ \\
\hline $\ln (\mathrm{GDP})$ & $\begin{array}{c}0.084^{* * *} \\
(3.85)\end{array}$ & $\begin{array}{l}0.096^{* * *} \\
(3.89)\end{array}$ & $\begin{array}{l}0.038^{* *} \\
(2.20)\end{array}$ & $\begin{array}{l}-0.014 \\
(-0.83)\end{array}$ & $\begin{array}{c}0.089 * * * \\
(4.64)\end{array}$ \\
\hline Tertiary & $\begin{array}{c}0.002^{* * *} \\
(2.85)\end{array}$ & $\begin{array}{c}0.002 * * * \\
(2.78)\end{array}$ & $\begin{array}{c}0.002^{* * *} \\
(3.19)\end{array}$ & $\begin{array}{c}0.002 * * * \\
(2.79)\end{array}$ & $\begin{array}{l}0.002 * * \\
(2.51)\end{array}$ \\
\hline Urbanization & $\begin{array}{l}-0.000 \\
(-0.65)\end{array}$ & $\begin{array}{l}-0.000 \\
(-0.69)\end{array}$ & $\begin{array}{l}-0.000 \\
(-0.82)\end{array}$ & $\begin{array}{l}-0.000 \\
(-1.33)\end{array}$ & $\begin{array}{l}-0.000 \\
(-1.27)\end{array}$ \\
\hline Indirect effect & & & & & \\
\hline $\ln (\mathrm{DOM})$ & $\begin{array}{l}-0.124^{* *} \\
(-2.37)\end{array}$ & $\begin{array}{c}-0.194^{* * *} \\
(-4.22)\end{array}$ & $\begin{array}{c}-0.239 * * * \\
(-5.99)\end{array}$ & $\begin{array}{c}-0.244^{* * *} \\
(-3.84)\end{array}$ & \\
\hline $\ln \left(\mathrm{DOM} \_\right.$Tourist $)$ & & & & & $\begin{array}{c}-0.299 * * * \\
(-5.36)\end{array}$ \\
\hline $\ln (\mathrm{GDP})$ & $\begin{array}{l}0.124 \\
(1.64)\end{array}$ & $\begin{array}{l}0.213^{* * *} \\
(3.25)\end{array}$ & $\begin{array}{l}0.392 * * * \\
(7.42)\end{array}$ & $\begin{array}{c}0.387^{* * *} \\
(4.64)\end{array}$ & $\begin{array}{c}0.253^{* * *} \\
(4.65)\end{array}$ \\
\hline Tertiary & $\begin{array}{l}0.002 \\
(0.42)\end{array}$ & $\begin{array}{l}0.001 \\
(0.40)\end{array}$ & $\begin{array}{l}-0.002 \\
(-0.99)\end{array}$ & $\begin{array}{l}-0.002 \\
(-0.51)\end{array}$ & $\begin{array}{l}0.004 \\
(1.14)\end{array}$ \\
\hline Urbanization & $\begin{array}{l}0.000 \\
(0.27)\end{array}$ & $\begin{array}{l}0.000 \\
(0.16)\end{array}$ & $\begin{array}{l}-0.000 \\
(-0.47)\end{array}$ & $\begin{array}{l}-0.000 * \\
(-1.68)\end{array}$ & $\begin{array}{l}0.000 \\
(0.29)\end{array}$ \\
\hline $\begin{array}{c}\text { Total effect } \\
\ln (\mathrm{DOM})\end{array}$ & $\begin{array}{l}-0.168^{* * *} \\
(-2.87)\end{array}$ & $\begin{array}{c}-0.251 * * * \\
(-4.69)\end{array}$ & $\begin{array}{c}-0.323 * * * \\
(-6.57)\end{array}$ & $\begin{array}{c}-0.299 * * * \\
(-4.30)\end{array}$ & \\
\hline $\ln \left(\mathrm{DOM} \_\right.$Tourist $)$ & & & & & $\begin{array}{c}-0.394^{* * *} \\
(-6.26)\end{array}$ \\
\hline
\end{tabular}


Table 4. Cont.

\begin{tabular}{|c|c|c|c|c|c|}
\hline & \multirow{3}{*}{$\begin{array}{c}\text { Baseline } \\
\text { FE Model }\end{array}$} & \multicolumn{4}{|c|}{ Robustness Check } \\
\hline & & \multicolumn{3}{|c|}{ With Alternative Spatial Weight Matrix } & \multirow{2}{*}{$\begin{array}{c}\text { Alternative Index of } \\
\text { Domestic Tourism }\end{array}$} \\
\hline & & $\mathbf{w}^{3-n e a r e s t}$ & $w^{15-h}$ & $\mathbf{w}^{\text {inverse-time-squared }}$ & \\
\hline \multirow{3}{*}{$\ln (\mathrm{GDP})$} & (1) & (2) & (3) & (4) & (5) \\
\hline & $0.208 * * *$ & $0.309 * * *$ & $0.430 * * *$ & $0.373^{* * *}$ & $0.342 * * *$ \\
\hline & $(2.64)$ & $(4.34)$ & $(6.67)$ & $(4.12)$ & $(5.93)$ \\
\hline \multirow[t]{2}{*}{ Tertiary } & 0.004 & 0.003 & 0.000 & 0.000 & 0.005 \\
\hline & $(0.82)$ & $(0.93)$ & $(0.08)$ & $(0.03)$ & $(1.47)$ \\
\hline \multirow[t]{2}{*}{ Urbanization } & 0.000 & 0.000 & -0.000 & $-0.000 *$ & 0.000 \\
\hline & $(0.15)$ & $(0.02)$ & $(-0.58)$ & $(-1.70)$ & $(0.07)$ \\
\hline
\end{tabular}

Notes: The numbers in parentheses represent $t$-stat values. ${ }^{* * *},{ }^{* *},{ }^{*}$ imply $1 \%, 5 \%$, and $10 \%$ level of significance, respectively. The dependent variable is $\ln (\mathrm{URII})$

In terms of other explanatory variables, the direct, indirect, and total effects are reported in column (1) of Table 4 . The direct effects of $\ln (\mathrm{GDP})$ and Tertiary are positive with a statistical significance at the $1 \%$ level, suggesting an improvement in economic development and localization economies would enlarge urban-rural income inequality in the local province. The direct effect of Urbanization is insignificant. The indirect effects of all the control variables are insignificant, suggesting no spatial effect of any control variable.

\subsection{Robustness Checks}

\subsubsection{Random Effect Spatial Durbin Model (RE-SDM)}

We consider the issue of model misspecification. Although the Hausman test supports FE-SDM, it is still beneficial to investigate whether our estimation results from the baseline model are sensitive to alternative model specifications. The estimated results from RE-SDM are similar to that from FE-SDM. RE-SDM results are not reported here for brevity but are available from the authors upon request.

\subsubsection{Alternative Spatial Weight Matrix}

Constructing the spatial weight matrix is crucial because different matrices' principles capture different channels of spillover effects [30]. However, there is strong theoretical and empirical evidence that worrying about the specification of the spatial weight matrix is not necessary [34]. This section tries to explore the sensitivity of the results to different spatial weight matrices for some other reasons.

For example, in tourism industries, we often talk about "day-trippers", "over-nighters", "extended-stay trippers", and "seasonal visitors". Each is defined by the length of time of the trip. Each of these different types of tourists has very different impacts on the destination economy. Here, distance can play a large role (e.g., day-trippers are very short distance trips and extended-stay trippers tend to travel much greater distances). Specifically, these different types of tourists spend their money very differently.

Hence, we test whether our baseline results are robust to the alternative spatial weight matrix setup. In the baseline model, we apply the queen contiguity weighting matrix $\mathrm{w}^{\text {neighbor }}$. Now, we exploit another geographical definition of spatial matrix $\mathrm{w}^{\mathrm{K}-\text { nearest }}$ $(\mathrm{K}=1,2,3, \ldots, 15)$. The diagonal elements $\mathrm{w}_{\mathrm{ii}}^{\mathrm{K}}$-nearest remain zero, and the off-diagonal element $\mathrm{w}_{\mathrm{ij}}^{\mathrm{K}}$-nearest is one if province $\mathrm{j}$ is within the K-nearest neighbors of province $\mathrm{i}$. (Here, the distance refers to the geographic distance between provincial capitals.) Since the east coastal provinces are relatively smaller than those of the western provinces, the K-nearest neighbors' criterion, capturing the spillover effects through the K-nearest geographical neighborhood channel, may lead to different results. The constructions of the above two forms of the spatial matrix are related to geographic information, including location and distance.

We also consider two types of spatial weight matrix based on the shortest time by railway. The first type is $\mathrm{w}^{\mathrm{T} \text {-hours }}(\mathrm{T}=10,15,24)$. The diagonal elements $\mathrm{w}_{\mathrm{ii}}^{\mathrm{T}-\text { hours }}$ are zero, and the off-diagonal element $\mathrm{w}_{\mathrm{ij}}^{\mathrm{T}}$-hours is one if the shortest length of railway time 
between capital cities of province $i$ and $j$ in 1995 is no more than T hours. The second type is $\mathrm{w}^{\text {inverse-time-(squared) }}$. The diagonal elements $\mathrm{w}_{\mathrm{ii}}$ inverse-time-(squared) are zero, and the offdiagonal element $w_{\mathrm{ij}}^{\text {inverse-time-(squared) }}$ is (the square of) the inverse of the shortest railway time between capital cities of provinces $i$ and $j$ in 1995. It is reasonable to assume that the above spatial matrices are exogenous, or at least predetermined, because the sample period is from 1998 to 2018.

Columns (2), (3), and (4) of Table 4 provide the direct, indirect, and total effects of $\ln (\mathrm{DOM})$ on $\ln (\mathrm{URII})$ with the spatial weight matrix $\mathrm{w}^{3 \text {-nearest }}, \mathrm{w}^{15-\mathrm{h}}$, and $\mathrm{w}^{\text {inverse-time-squared, }}$ respectively. All the results find significantly negative direct and indirect effects of $\ln (\mathrm{DOM})$ on $\ln (\mathrm{URII})$, and the magnitudes are all greater than the corresponding effects in the baseline model.

Figures 3 and 4 visualize the direct and indirect effects of $\ln (\mathrm{DOM})$ on $\ln (\mathrm{URII})$ with the spatial weight matrix $\mathrm{w}^{\mathrm{K} \text {-nearest }}(\mathrm{K}=1,2,3, \ldots, 15), \mathrm{w}^{\mathrm{T} \text {-hours }}(\mathrm{T}=10,15,24)$, $\mathrm{w}^{\text {inverse-time-squared }}$, and $\mathrm{w}^{\text {inverse-time }}$, respectively. They show that longer distance travelers, or extended-stay tripper, have a much stronger impact on incomes than short-distance day-trippers. The results indicate that the findings are robust to using weight matrices based on the geographical distance and the shortest railway time.

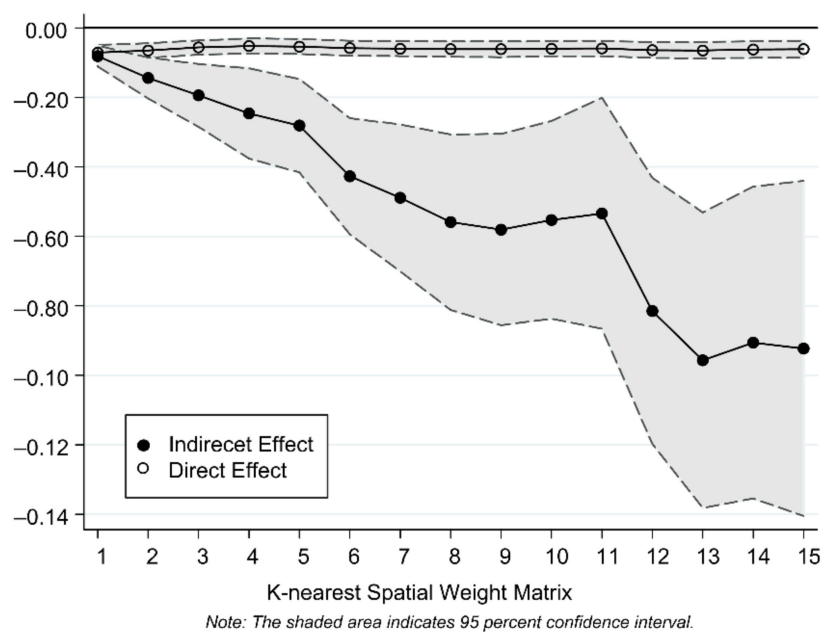

Figure 3. The direct and indirect effects of $\ln (\mathrm{DOM})$ on $\ln (\mathrm{URII})$ (using K-nearest spatial weight matrix, $K=1,2, \ldots, 15)$.

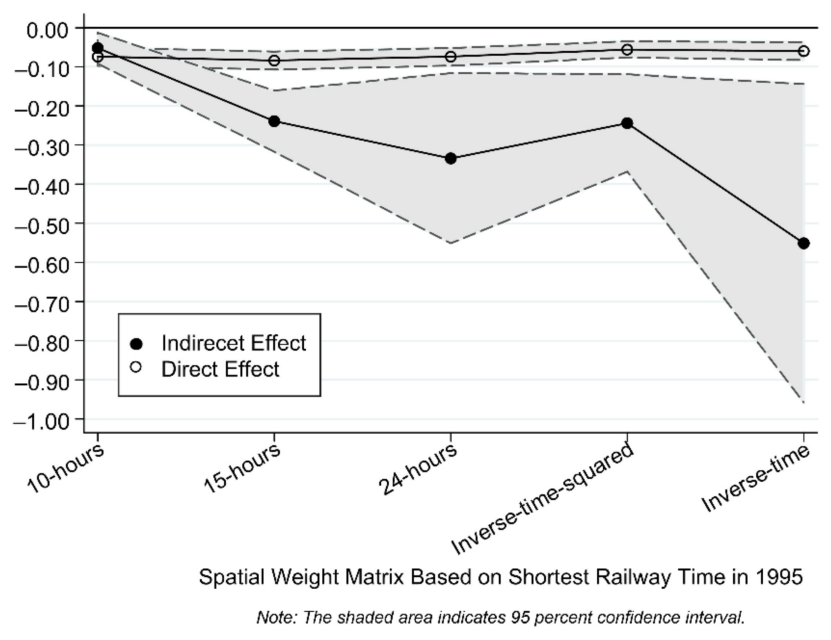

Figure 4. The direct and indirect effects of $\ln (\mathrm{DOM})$ on $\ln (\mathrm{URII})$ (using different types of spatial weight matrices based on the shortest railway time in 1995). 


\subsubsection{Alternative Measure of Domestic Tourism}

In this section, we consider whether the regression is robust to alternative measure of domestic tourism. In the baseline model shown in column (1) of Table 4, the key explanatory variable is $\ln (\mathrm{DOM})$, the logarithmic value of domestic tourism revenue (in 100 million RMB Yuan, 2010 prices) in a province during one year. The amount of domestic tourism revenue is a straightforward measure of the domestic tourism industry. However, domestic tourism revenue may not accurately capture the domestic tourism development level. For example, a higher domestic tourism revenue may come from high domestic tourists' average expenditure but low domestic tourist arrivals. Therefore, we replace the key explanatory variable with $\ln \left(\mathrm{DOM} \_\right.$Tourist), which is equal to the logarithmic value of the number of domestic tourist arrivals (10,000 person-times). It provides a measure of domestic tourism development from a different aspect [7]. Column (5) of Table 4 reports the corresponding direct, indirect, and total effects of $\ln (\mathrm{DOM}$-Tourist) on $\ln (\mathrm{URII})$. The key elasticities are twice to triple of the baseline estimates and become statistically more significant, corroborating the baseline findings.

\subsection{Extended Analyses}

\subsubsection{Regional Disparate Effects}

Considering that the degrees of social and economic development are highly heterogeneous across western, central, and eastern regions in China [22], it is necessary to check whether the impact of domestic tourism on urban-rural income inequality is homogeneous over these three regions. To this end, we re-estimate the baseline model for three subsamples separately and then compare the results. The sample is divided into three regions following Liu, Nijkamp, and Lin's previous empirical study [20]. Columns (1), (3), and (5) in Table 5 display the estimated direct, indirect, and total effects of $\ln (\mathrm{DOM})$ on $\ln$ (URII) for the eastern, central, and western subsamples, respectively. There are three main findings:

1. In the western and eastern regions, domestic tourism revenue generates a significant negative impact on urban-rural income inequality in local provinces.

2. In all regions, domestic tourism has no significant spatial spillover effect on urbanrural income inequality in the neighboring provinces. Considering the significantly negative indirect effect of domestic tourism on urban-rural income at the national level, the results suggest that domestic tourism in a province may reduce urban-rural income inequality in the neighboring provinces if they are not in the same region; the improving effects may disappear if they are in the same region.

3. Notably, in eastern regions, the indirect effect is positive and statistically significant at the $5 \%$ level.

Table 5. The estimated direct, indirect, and total effects of domestic tourism on URII (Extended Analyses).

\begin{tabular}{|c|c|c|c|c|c|c|c|}
\hline & Western & & Central & & Eastern & & National \\
\hline $\begin{array}{c}\text { Dependent Variable: } \\
\ln (\text { URII) }\end{array}$ & (1) & (2) & (3) & (4) & (5) & (6) & (7) \\
\hline $\begin{array}{l}\text { Direct effect } \\
\ln (\mathrm{DOM})\end{array}$ & $\begin{array}{c}-0.071 \text { ** } \\
(-2.53)\end{array}$ & & $\begin{array}{l}0.002 \\
(0.07)\end{array}$ & & $\begin{array}{c}-0.049^{* *} \\
(-2.55)\end{array}$ & & \\
\hline $\ln \left(\mathrm{DOM} \_\right.$Tourist $)$ & & $\begin{array}{c}-0.180 * * * \\
(-6.96)\end{array}$ & & $\begin{array}{l}-0.013 \\
(-0.54)\end{array}$ & & $\begin{array}{c}-0.055^{* *} \\
(-2.40)\end{array}$ & $\begin{array}{c}-0.095^{* * *} \\
(-8.76)\end{array}$ \\
\hline $\ln ($ DOM_Expenditure) & & $\begin{array}{c}0.180^{* * *} \\
(6.31)\end{array}$ & & $\begin{array}{c}0.03 \\
(1.47)\end{array}$ & & $\begin{array}{l}0.034 \\
(0.90)\end{array}$ & $\begin{array}{c}0.070^{* * *} \\
(5.08)\end{array}$ \\
\hline $\begin{array}{l}\text { Indirect effect } \\
\ln (\mathrm{DOM})\end{array}$ & $\begin{array}{l}-0.131 \\
(-1.10)\end{array}$ & & $\begin{array}{c}0.06 \\
(0.95)\end{array}$ & & $\begin{array}{c}0.080 * * \\
(2.13)\end{array}$ & & \\
\hline $\ln$ (DOM_Tourist) & & $\begin{array}{c}-0.493^{* * *} \\
(-4.63)\end{array}$ & & $\begin{array}{l}-0.082 \\
(-1.37)\end{array}$ & & $\begin{array}{l}0.095^{*} \\
(1.85)\end{array}$ & $\begin{array}{l}-0.286^{* * *} \\
(-6.25)\end{array}$ \\
\hline ln(DOM_Expenditure) & & $\begin{array}{c}0.388^{* * *} \\
(4.14)\end{array}$ & & $\begin{array}{c}0.192 * * * \\
(3.82)\end{array}$ & & $\begin{array}{l}0.216^{* * *} \\
(2.59)\end{array}$ & $\begin{array}{c}0.283^{* * *} \\
(4.80)\end{array}$ \\
\hline
\end{tabular}


Table 5. Cont.

\begin{tabular}{|c|c|c|c|c|c|c|c|}
\hline & Western & & Central & & Eastern & & National \\
\hline $\begin{array}{c}\text { Dependent Variable: } \\
\ln (\text { URII) }\end{array}$ & (1) & (2) & (3) & (4) & (5) & (6) & (7) \\
\hline $\begin{array}{l}\text { Total effect } \\
\ln (\mathrm{DOM})\end{array}$ & $\begin{array}{l}-0.202 \\
(-1.41)\end{array}$ & & $\begin{array}{l}0.061 \\
(0.75)\end{array}$ & & $\begin{array}{l}0.031 \\
(0.62)\end{array}$ & & \\
\hline $\ln (\mathrm{DOM}$ _Tourist) & & $\begin{array}{c}-0.673 * * * \\
(-5.26)\end{array}$ & & $\begin{array}{l}-0.095 \\
(-1.23)\end{array}$ & & $\begin{array}{c}0.04 \\
(0.64)\end{array}$ & $\begin{array}{c}-0.381 * * * \\
(-7.31)\end{array}$ \\
\hline ln(DOM_Expenditure) & & $\begin{array}{l}0.567 * * * \\
(5.23)\end{array}$ & & $\begin{array}{l}0.222 * * * \\
(3.44)\end{array}$ & & $\begin{array}{l}0.250 * * \\
(2.19)\end{array}$ & $\begin{array}{c}0.353^{* * *} \\
(5.25)\end{array}$ \\
\hline
\end{tabular}

Notes: The numbers in parentheses represent t-stat value. Superscripts ***,**,* imply 1\%, 5\%, and $10 \%$ level of significance, respectively. The western provinces include Chongqing, Gansu, Guizhou, Ningxia, Qinghai, Shaanxi, Sichuan, Xizang, Xinjiang, and Yunnan; the central provinces include Anhui, Guangxi, Henan, Heilongjiang, Hubei, Hunan, Inner Mongolia, Jiangxi, Jilin, and Shanxi; and the eastern provinces include Beijing, Fujian, Guangdong, Hainan, Hebei, Jiangsu Liaoning, Shandong, Shanghai Tianjin, and Zhejiang.

\subsubsection{Decomposition of Domestic Tourism Revenue}

In order to further investigate potential underlying channels through which domestic tourism affects the urban-rural income ratio, we divide the domestic tourism revenue into the product of the number of domestic tourist arrivals and average expenditure. That is,

$$
\ln (\mathrm{DOM})_{\mathrm{it}} \equiv \ln \left(\mathrm{DOM} \_ \text {Tourist }\right)_{\mathrm{it}}+\ln \left(\mathrm{DOM} \_ \text {Expenditure }\right)_{\mathrm{it}}
$$

We use these two variables to replace the original explanatory variable $\ln (\mathrm{DOM})$. Column (7) in Table 5 displays the estimated direct, indirect, and total effects of $\ln$ (DOM_Tourist) and $\ln (\mathrm{DOM}$ _Expenditure) on $\ln (\mathrm{URII})$. An increase in domestic tourist arrivals reduces the urban-rural income ratio in the local and neighboring provinces, which is in line with our previous findings. However, an increase in domestic tourists' average expenditure increases the urban-rural income ratio in the local and the neighboring provinces.

\subsubsection{Decomposition of Domestic Tourism Revenue and Regional Disparate Effects}

The decomposition exercise and the regional subsample analyses performed in Sections 4.4.1 and 4.4.2 shed new light on how domestic tourism may reduce urban-rural income inequality. In this section, we combine these two. Columns (2), (4), and (6) in Table 5 display the estimated direct, indirect, and total effects of $\ln (\mathrm{DOM}$ _Tourist) and $\ln (\mathrm{DOM}$ _Expenditure) on $\ln (\mathrm{URII})$ for the eastern, central, and western subsamples, respectively.

In the western region, the indirect effects in columns (1) and (2) of Table 5 suggest three things. (1) The local urban-rural income inequality would decrease by $0.493 \%$ if the number of domestic tourist arrivals in neighboring provinces simultaneously increased by $1 \%$. (2) The local urban-rural income inequality would increase by $0.388 \%$ if domestic tourists' average expenditure in neighboring provinces simultaneously increased by $1 \%$. (3) These two spatial effects are of a different sign in the western provinces, rendering a statistically insignificant spatial spillover effect of $\ln (\mathrm{DOM})$ on $\ln (\mathrm{URII})$.

For the central provinces, the indirect effects in columns (3) and (4) of Table 5 also indicate three things. (1) The local urban-rural income inequality would increase by $0.192 \%$ if domestic tourists' average expenditure in neighboring provinces simultaneously increased by $1 \%$. (2) The local urban-rural income inequality would not be affected by the neighboring provinces' number of domestic tourists. (3) Hence, the spatial spillover effect of $\ln (\mathrm{DOM})$ on $\ln (\mathrm{URII})$ for the central region is non-negative.

In the eastern region, the indirect effects in columns (5) and (6) of Table 5 imply three things. (1) The local urban-rural income inequality would increase by $0.216 \%$ if domestic tourists' average expenditure in neighboring provinces simultaneously increased by $1 \%$. (2) The local urban-rural income inequality would increase by $0.095 \%$ if the neighboring provinces' number of domestic tourist arrivals simultaneously increased by $1 \%$. (3) Consequently, the spatial spillover effect of $\ln (\mathrm{DOM})$ on $\ln (\mathrm{URII})$ for the eastern regions is significantly positive. 


\section{Discussion and Implications}

\subsection{The Direct Effects}

Hypothesis 1 is supported at the national level. Among 31 provinces, developing domestic tourism is an effective way to reduce urban-rural income inequality. The result is consistent with Williams and Shaw [14], whose study supports that tourism distributes development from developed areas to less developed areas. This study supplements the literature by investigating domestic tourism's impact on urban-rural income inequality.

Hypothesis 1 is partially supported at the regional level. The role of domestic tourism in reducing local urban-rural income inequality is only evident in the western and eastern regions, not in the central region. Compared with international tourism, domestic tourism has a broader scope for reducing the income gap between urban and rural areas, because Shi et al. [22] only find a significantly negative impact of inbound tourism revenue on urban-rural income inequality in the western region, not in the central and eastern regions. Moreover, domestic tourism's role in reducing local urban-rural income inequality in western and eastern China is through domestic tourists' flows. This finding is in line with Shahbaz et al. [35], who find that tourist arrivals and tourism revenue lower income inequality in the Malaysian economy. Other things being equal, an increase in domestic tourists' average expenditure may increase local urban-rural income inequality in western China.

The results on the direct effects provide two pieces of insights. First, it might be more effective for provinces in western and eastern China to implement policies that attract more domestic tourist arrivals. Second, for western provinces, blindly driving up the level of domestic tourism expenditure may inadvertently increase urban-rural income inequality.

\subsection{The Spatial Spillover Effects}

Hypothesis 2 is supported at the national level. Increasing domestic tourism revenue in neighboring provinces tends to reduce the local province's urban-rural income inequality. Moreover, the spatial spillover effects become stronger when more provinces within a close geographical proximity or less railway travel time are considered.

However, Hypothesis 2 is not supported at the regional level. In all three regions, domestic tourism revenues in the neighboring provinces have no significant role in reducing urban-rural income inequality in the local province. In eastern regions, domestic tourism revenues in the neighboring provinces may significantly increase urban-rural income inequality in the local province.

The results on the indirect effects also provide two pieces of insights. First, within the same region, it may not be effective to reduce urban-rural income inequality in the local province by developing domestic tourism revenue in the neighboring provinces. Second, among 31 provinces, it is effective to reduce urban-rural income inequality in the local province by developing domestic tourism revenue in the neighboring provinces, especially when the provinces are in the borders of regions.

\subsection{Domestic Tourists versus Domestic Tourism Expenditure}

Regarding attracting domestic tourists, a collaborative strategy, a low-priority strategy, and a mitigation strategy are suitable for western, central, and eastern provinces, respectively. An increase in the number of neighboring provinces' domestic tourist arrivals decreases the local province's urban-rural income inequality in western China, while the effect is insignificant in central China, and the effect is even in the opposite direction in eastern China.

Besides, blindly driving up the level of domestic tourism expenditure may increase the urban-rural income ratio in the province. An increase in neighboring provinces' domestic tourism expenditure levels decreases the local province's urban-rural income inequality in all three regions. 


\section{Conclusions, Limitations, and Future Studies}

This empirical work brings light to an interdisciplinary concern that regards income inequality, tourism development, and spatial econometrics. Most research has explored the relationship between domestic tourism and income inequality among regions, provinces, and cities, while few studies have examined the impact of domestic tourism on income inequality between the urban and rural areas within a region. As far as we known, this is the first paper to examine the spatial effects of domestic tourism on urban-rural income inequality.

Using a panel spatial Durbin model, this study empirically investigates the spatial effect of domestic tourism development on urban-rural income inequality within 31 Chinese provinces from 1998 to 2018. In the baseline study, we examine the spillover effects by using weight matrices based on geographical location. In the robustness checks, we apply weight matrices based on the geographical distance and the shortest railway time.

Results at the national level show that domestic tourism revenue in the local and the neighboring provinces significantly reduce urban-rural income inequality in the local province. Results at regional levels indicate that domestic tourism revenue in the local province can significantly reduce urban-rural income inequality in the local province, but it has no obvious effect on urban-rural income inequality in the neighboring provinces.

Innovatively, we decompose domestic tourism revenue and consider the circumstances in different regions. We find that an increase in the number of domestic tourists' arrival in neighboring provinces decreases the local province's urban-rural income inequality in the western region but increases the inequality in the eastern region, while the effect is insignificant in the central region. Second, driving up the level of domestic tourism expenditure may increase the urban-rural income ratio in the neighboring provinces for all regions, and even increase the urban-rural income ratio in the local province for the western region.

Two policy suggestions can be derived from these results. First, as for attracting domestic tourists, the results suggest a collaborative strategy for the western region, a low-priority strategy for the central region, and a mitigation strategy for the eastern region. Second, do not waste limited promotional efforts on nearby places. Developing a balance in promotional materials, which focus on places farther away instead of nearby places, might have the effect of reducing the urban-rural income inequality within a province.

This study is subject to a number of limitations. First, this study only considers the effect of the total domestic tourism, it does not distinguish between the impact of domestic tourism in urban areas and rural areas because of the limitation of data availability. It could be promising to consider urban domestic tourism and rural domestic tourism's separate roles in reducing urban-rural income inequality. Second, this study utilizes Chinese data, and it is still unknown whether the findings apply to other economies or countries. Future studies could assess domestic tourism's impact on the urban-rural income inequality in other countries, especially for those countries suffering severe income inequality problems.

Author Contributions: Conceptualization, Z.Z. and X.W.; methodology, Z.Z. and X.W.; software, Z.Z.; validation, Z.Z.; formal analysis, Z.Z.; investigation, X.W.; resources, Z.Z.; data curation, Z.Z.; writing-review and editing, Z.Z. and X.W.; visualization, Z.Z.; supervision, X.W.; project administration, X.W.; funding acquisition, X.W. Both authors have read and agreed to the published version of the manuscript.

Funding: This research was funded by the China National Natural Science Foundation, grant number 71673079 .

Data Availability Statement: The data will be made available on request from the corresponding author.

Acknowledgments: We want to acknowledge Shen Gao, Long Zhao, Yaqin Su, Chenghan Hou and Qiang Wang.

Conflicts of Interest: The authors declare no conflict of interest. 


\section{Appendix A}

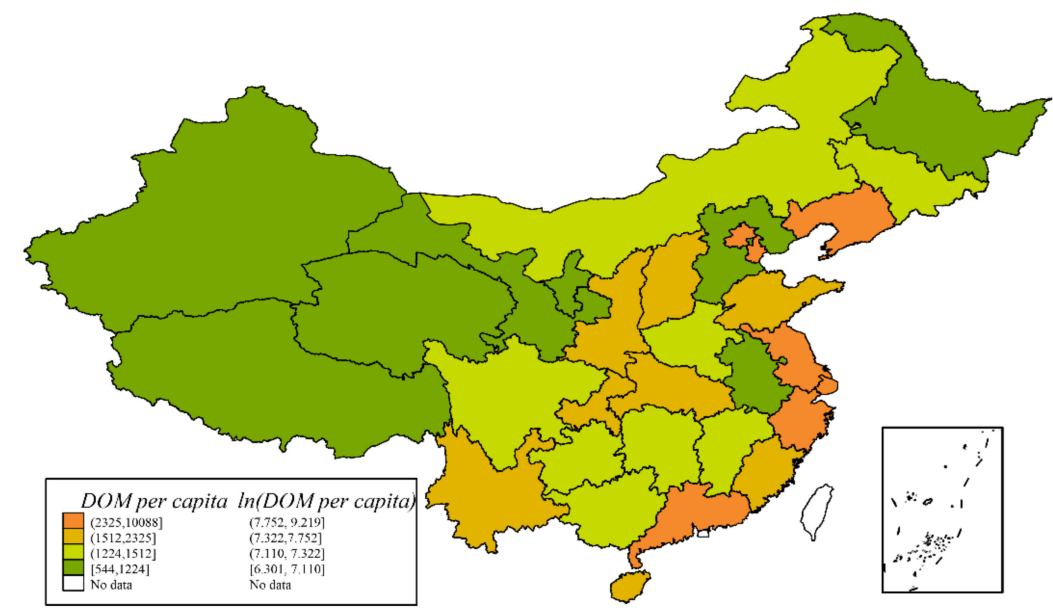

Figure A1. Spatial distribution of $\ln (\mathrm{DOM}$ per capita) (average value from 1998 to 2018). $\ln (\mathrm{DOM}$ per capita) is the logarithm of the real revenue of domestic tourism per capita (RMB Yuan per capita, at 2010 prices).

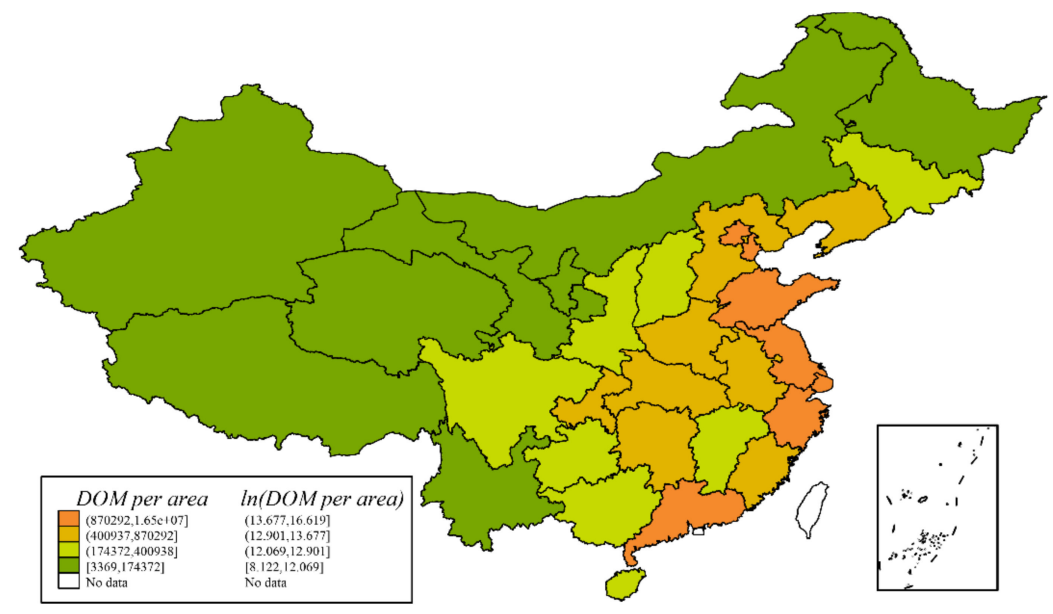

Figure A2. Spatial distribution of $\ln (\mathrm{DOM}$ per area) (average value from 1998 to 2018). $\ln (\mathrm{DOM}$ per area) is the logarithm of the real revenue of domestic tourism per area (RMB Yuan per square kilometer, at 2010 prices).

\section{References}

1. Kuijs, L.; Wang, T. China's pattern of growth: Moving to sustainability and reducing inequality. China World Econ. 2006, 14, 1-14. [CrossRef]

2. Mahadevan, R.; Suardi, S. Panel evidence on the impact of tourism growth on poverty, poverty gap and income inequality. Curr. Issues Tour. 2019, 22, 253-264. [CrossRef]

3. Folarin, O.; Adeniyi, O. Does Tourism Reduce Poverty in Sub-Saharan African Countries? J. Travel Res. 2020, 59, 140-155. [CrossRef]

4. Li, H.; Chen, J.L.; Li, G.; Goh, C. Tourism and regional income inequality: Evidence from China. Ann. Tour. Res. 2016, 58, 81-99. [CrossRef]

5. Truong, V.D.; Hall, C.M.; Garry, T. Tourism and poverty alleviation: Perceptions and experiences of poor people in Sapa, Vietnam. J. Sustain. Tour. 2014, 22, 1071-1089. [CrossRef]

6. Haddad, E.A.; Porsse, A.A.; Rabahy, W. Domestic tourism and regional inequality in Brazil. Tour. Econ. 2013, 19, 173-186. [CrossRef]

7. Llorca-Rodríguez, C.M.; García-Fernández, R.M.; Casas-Jurado, A.C. Domestic versus inbound tourism in poverty reduction: Evidence from panel data. Curr. Issues Tour. 2020, 23, 197-216. [CrossRef]

8. Ma, T.; Hong, T.; Zhang, H. Tourism spatial spillover effects and urban economic growth. J. Bus. Res. 2015, 68, 74-80. [CrossRef] 
9. Goh, C.; Li, H.; Qiu, Z. Achieving balanced regional development in China: Is domestic or international tourism more efficacious ? Tour. Econ. 2015, 21, 369-386. [CrossRef]

10. Lakner, C.; Milanovic, B. Global income distribution: From the fall of the berlinwall to the great recession. World Bank Econ. Rev. 2016, 30, 203-232. [CrossRef]

11. Sicular, T.; Ximing, Y.; Gustafsson, B.; Shi, L. The Urban-rural Income Gap and Inequality in China. Rev. Income Wealth 2007, 53, 93-126. [CrossRef]

12. National Data. Available online: https:/ / data.stats.gov.cn (accessed on 31 August 2020).

13. Chang, G.H. The cause and cure of China's widening income disparity. China Econ. Rev. 2002, 13, 335-340. [CrossRef]

14. Williams, A.M.; Shaw, G. Tourism and Economic Development: Western European Experiences; Williams, A.M., Shaw, G., Eds.; Belhaven Press: London, UK, 1991.

15. Blake, A.; Arbache, J.S.; Sinclair, M.T.; Teles, V. Tourism and poverty relief. Ann. Tour. Res. 2007, 35, 107-126. [CrossRef]

16. Mitchell, J.; Ashley, C. Tourism and Poverty Reduction: Pathways to Prosperity; Earthscan: London, UK, 2009; ISBN 9781849774635.

17. Deller, S. Rural poverty, tourism and spatial heterogeneity. Ann. Tour. Res. 2010, 37, 180-205. [CrossRef]

18. Fang, J.; Gozgor, G.; Paramati, S.R.; Wu, W. The impact of tourism growth on income inequality: Evidence from developing and developed economies. Tour. Econ. 2020, 1354816620. [CrossRef]

19. Alam, M.S.; Paramati, S.R. The impact of tourism on income inequality in developing economies: Does Kuznets curve hypothesis exist? Ann. Tour. Res. 2016, 61, 111-126. [CrossRef]

20. Liu, J.; Nijkamp, P.; Lin, D. Urban-rural imbalance and Tourism-Led Growth in China. Ann. Tour. Res. 2017, 64, 24-36. [CrossRef]

21. Zhao, L. Can tourism development reduce the urban-rural income gap? An empirical evidence from China. Tour. Trib. 2011, 26, 15-25.

22. Shi, W.; Luo, M.; Jin, M.; Cheng, S.K.; Li, K.X. Urban-rural income disparity and inbound tourism: Spatial evidence from China. Tour. Econ. 2020, 26, 1231-1247. [CrossRef]

23. Sampson, R.J. Neighbourhood effects and beyond: Explaining the paradoxes of inequality in the changing American metropolis. Urban Stud. 2019, 56, 3-32. [CrossRef]

24. Reardon, S.F.; Bischoff, K. Income Inequality and Income Segregation. Am. J. Sociol. 2011, 116, 1092-1153. [CrossRef] [PubMed]

25. Liu, Y.; Liu, J.; Zhou, Y. Spatio-temporal patterns of rural poverty in China and targeted poverty alleviation strategies. J. Rural. Stud. 2017, 52, 66-75. [CrossRef]

26. Patuelli, R.; Mussoni, M.; Candela, G. The effects of World Heritage Sites on domestic tourism: A spatial interaction model for Italy. J. Geogr. Syst. 2013, 15, 369-402. [CrossRef]

27. Alvarez-Diaz, M.; D’Hombres, B.; Ghisetti, C.; Pontarollo, N. Analysing domestic tourism flows at the provincial level in Spain by using spatial gravity models. Int. J. Tour. Res. 2020, 22, 403-415. [CrossRef]

28. Kang, S.; Kim, J.; Nicholls, S. National Tourism Policy and Spatial Patterns of Domestic Tourism in South Korea. J. Travel Res. 2014, 53, 791-804. [CrossRef]

29. Yang, Y.; Fik, T. Spatial effects in regional tourism growth. Ann. Tour. Res. 2014, 46, 144-162. [CrossRef]

30. Lesage, J.; Pace, R.K. Introduction to Spatial Econometrics; Chapman \& Hall/CRC: Boca Raton, FL, USA, 2009 ; ISBN 2008038890.

31. Anselin, L. Spatial Econometrics: Methods and Models; Kluwer Academic Publishers: Dordrecht, The Netherlands, 1988; ISBN 9048183111.

32. Huang, Q.; Chand, S. Spatial spillovers of regional wages: Evidence from Chinese provinces. China Econ. Rev. 2015, 32, 97-109. [CrossRef]

33. National Bureau of Raiway Transport of China. National Railway Passenger Timetable (1995-1996); China Railway Press: Beijing, China, 1995.

34. Lesage, J.P.; Pace, R.K. The Biggest Myth in Spatial Econometrics. Econometrics 2014, 2, 217-249. [CrossRef]

35. Shahbaz, M.; Solarin, S.A.; Azam, M.; Tiwari, A.K. Tourism-induced income distribution in Malaysia: A practical experience of a truly Asian economy. Curr. Issues Tour. 2020, 23, 2910-2929. [CrossRef] 